\title{
Utilization of the intertidal zone of a salt marsh by the blue crab Callinectes sapidus: density, return frequency, and feeding habits
}

\author{
H. Carlton Fitz ${ }^{1, *}$, Richard G. Wiegert ${ }^{2}$ \\ ${ }^{1}$ Institute of Ecology, University of Georgia, Athens, Georgia 30602, USA \\ ${ }^{2}$ Department of Zoology and Institute of Ecology, University oi Georgia, Athens, Georgia 30602, USA
}

\begin{abstract}
The extent to which the blue crab Callinectes sapidus utilizes resources within the intertidal zone of salt marshes has not been quantified in a rigorous manner In the salt marshes of Sapelo Island, Georgia (USA), we sampled blue crabs using block nets as the crabs moved out of defined intertidal areas, determining the timing and extent of movement into, and feeding habits within, intertidal habitats. Blue crabs were absent or had an extremely low density within an intertidal marsh impoundment during winter, when water temperature was below $\mathrm{ca} 15^{\circ} \mathrm{C}$. Juveniles $\leq 80 \mathrm{~mm}$ carapace width started moving into the intertidal zone in March or April, but the intertidal density of blue crabs was dominated by larger juveniles and adults $(>80 \mathrm{~mm})$ throughout the summers of the $2.5 \mathrm{yr}$ study (March 1985 to August 1987). Densities were not large, peaking at 40 to $50 \mathrm{crabs} \mathrm{ha}^{-1}$ (of total area sampled) during September. A non-impounded site located in a different local region had similar total densities to those of the impoundment, but had significantly more juveniles $\leq 80 \mathrm{~mm}$. Comparison of the size frequency distributions of blue crabs captured in the non-impounded intertidal area and in a nearby subtidal creek showed that all sizes of crabs $(\geq 35 \mathrm{~mm})$ moved into the intertidal zone of the marsh durng the summer in approximate proportion to their abundance within the source (subtidal) population. On a shorter time scale during May-June, we captured more crabs in the impoundment during daytime vs nocturnal high tides. The extent of tidal inundation did not appear to greatly affect abundance here, although abundance during the lowest of the tidal heights was somewhat less than that during intermediate and high tidal heights. The principal prey consumed by relatively large (mostly $>100 \mathrm{~mm}$ ) blue crabs within the study zone were natant fishes $(38 \%)$ and resident non-portunid crabs $(43 \%)$. Shrimp and similar crustaceans formed $12 \%$ of the diet; other invertebrates such as gastropods and annelids a very small portion. Returns of individual blue crabs to the same intertidal marsh zone primarily occurred within $10 \mathrm{~d}$ of their initial capture, after which they apparently emigrated from the local area. This study provides the most complete synthesis available of the timing and extent to which blue crabs use the intertidal habitat of the salt marsh.
\end{abstract}

\section{INTRODUCTION}

'For reasons not completely understood, a small number of crabs will climb up on to the marshland and blunder through the Spartina grass like miniature Sherman tanks.'

From William W. Warner's Beautiful Swimmers (1976)

Little, Brown and Co., Boston

The general life history characteristics of the blue crab Callinectes sapidus have been documented for most regions where it is common (Churchill 1919, Dar-

\footnotetext{
- Present address: Chesapeake Biological Laboratory, Center for Environmental and Estuarine Studies, University of Maryland, Solomons, Maryland 20688, USA.
}

nell 1959, Tagatz 1968, Archambault et al. 1990). These studies and others (including Dudley \& Judy 1973. Perry 1975, Hines et al. 1987) have also provided a basic understanding of the population ecology of blue crabs in various geographic regions, from the Gulf of Mexico coast to Chesapeake Bay, USA. However, patterns of habitat utilization by blue crabs in these diverse regions are poorly understood. The shallow subtidal zones of salt marsh creeks are known to be inhabited by blue crabs (e.g. Dudley \& Judy 1973, Perry 1975, Weinstein 1979, Subrahmanyam \& Coultas 1980, Orth \& van Montfrans 1987, Thomas et al. 1990 , Wilson et al. 1990); Fitz (1990) presented more detailed population dynamics of blue crabs within the shallow upper reaches of a subtidal creek of a Georgia salt 
marsh estuary. Although blue crabs have been reported to move into the intertidal area of polyhaline (Shenker \& Dean 1979, Arnold \& Kneib 1983, Zimmerman \& Minello 1984. Thomas et al. 1990) and oligohaline (Rozas \& Hackney 1984) marshes, few data exist on the extent of the utilization of intertidal Spartina alterniflora salt marshes by this large decapod crustacean - this 'Sherman tank'

Patterns of utilization of salt marshes by natant macrofauna may change depending on the availability of the Spartina marsh surface and the presence of other vegetated habitats. The salt marshes of Georgia are among the most extensive of the east coast of the USA and are inundated twice daily by the tides. The tidal amplitude (ca 1.5 to $3 \mathrm{~m}$ ) is larger than in most other areas where blue crabs are common, with a regular and relatively brief pattern of flooding compared to that usually found along the coast of the Gulf of Mexico. Another contrast between Georgia and most other areas of blue crab abundance is the absence of subtidal seagrass beds, which are considered to be important habitats for juvenile blue crabs (Orth \& van Montfrans 1987) in many other locations, from the Gulf coast to Chesapeake Bay.

There are a number of factors that should be considered in quantifying blue crabs' utilization of salt marsh intertidal areas. First, the extent to which both juvenile and adult blue crabs move on to the marsh is unknown, and it is important to sample on an appropriate temporal (and spatial) scale. There are seasonal changes in local population size structure, abundance and activity (e.g. Dudley \& Judy 1973, Hines et al. 1987, Orth \& van Montfrans 1987, Fitz 1990), while the extent and duration of marsh inundation changes substantially on daily, weekly and seasonal scales as tidal amplitude varies. Abundance estimates of blue crabs in the intertidal zone of salt marshes are scarce, and are derived from limited sampling ( 1 mo in Shenker \& Dean 1979) or concern very small juveniles during $1 \mathrm{yr}$ in a very different salt marsh system in the Gulf of Mexico (Zimmerman \& Minello 1984, Thomas et al. 1990\}. Second, blue crabs prey on a variety of fishes and invertebrates (Darnell 1958, Tagatz 1968, Laughlin 1982, Fitz 1990) which can be found in both subtidal and intertidal areas. However, the general types of prey that freeranging blue crabs obtain while within the intertidal zone is unknown. Finally, the frequency with which blue crabs return to the same intertidal site is unknown. Blue crabs are a possible vector of carbon transport from the intertidal area, (potentially) consuming resources and leaving with the tide. While the total number of crabs utilizing resources within a marsh may remain constant, local population turnover can occur through emigration/immigration, thus affecting estimates of gross loss rate from the local marsh system.

It is difficult to sample motile organisms within inter- tidal salt marshes due to the problem of gaining access to the marsh zones without disturbing the targeted organisms. Zimmerman \& Minello (1984) deployed a drop cylinder along the periphery of small salt marsh patches, but that was impractical for larger expanses of marsh such as those in Georgia. Channel nets (Bozeman \& Dean 1980) and flume nets (Mclvor \& Odum 1986) sample natant organisms as the tide recedes from a large area, thus circumventing the problems of point sampling within the expanse of dense vegetation in the marsh. We sampled blue crabs within 2 intertidal zones of the salt marsh, establishing a block net system across the small intertidal creek which drained each area. Our goals were to determine (1) changes in abundance over a 2.5 yr period; (2) on a shorter time scale, the extent to which tidal amplitude and time of day affect abundance; (3) the frequency with which individual blue crabs return to the same intertidal area; (4) the general prey categories of free-ranging blue crabs; and (5) from trawl tows in the adjacent subtidal creeks, the potential difference in sizes of blue crabs in the subtidal (source) population and in the intertidal zone. These objectives, which have not been addressed previously, are fundamental to a better understanding of the use of intertidal zone of salt marshes by this motile consumer.

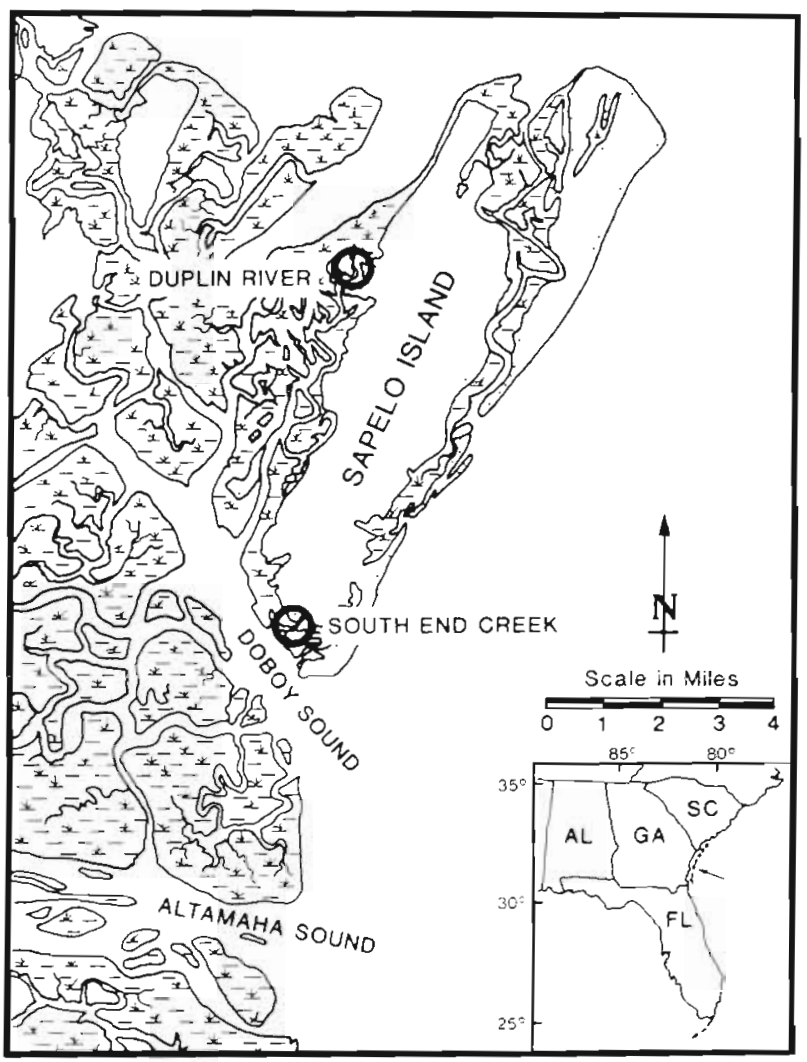

Fig. 1. Approximate locations of the sampling sites in the intertidal zone of salt marshes of the Duplin River (DUP) and South End Creek (SEC), Georgia, USA 


\section{METHODS}

Study sites and sampling system. The 2 study sites were located in the salt marshes along Sapelo Island, Georgia, as indicated in Fig. 1: the primary site was along South End Creek (SEC), which drains into Doboy Sound in close proximity to the Atlantic Ocean. The SEC site was a diked impoundment established ca 25 yr prior to the study. Using measurements from ground-truthed aerial photographs, total surface area within the dike was 0.29 ha; open water composed $6 \%$ of the total, while zones of tall, intermediate, and short forms of Spartina covered ca 7, 35, and $52 \%$ of the total area, respectively. The impoundment drains completely at low tide via a $2.5 \mathrm{~m}$ wide creek, which then passes along a zone of tall Spartina marsh and into South End Creek. Though the impoundment was not a completely natural marsh, it had been open to complete water exchange for more than a decade and provided a controlled habitat which was an approximation to other more natural sites.

At SEC, we erected a frame structure between the sloping banks of the drainage creek, extending a 0.64 $\mathrm{cm}$ square mesh wire fence from each frame side to a point on the dike. The block net $(1.6 \mathrm{~m}$ wide by $1.6 \mathrm{~m}$ high at the mouth) was deployed at high tide by lowering rigid pipes attached to the net into larger diameter, slotted pipes alongside the frame structure. For the first year, the block net had a $1.2 \mathrm{~cm}$ square knotted mesh, but this was replaced with a net having $0.64 \mathrm{~cm}$ square knotless mesh for the remainder of the study. Despite the smaller mesh size, we found no measurable change towards capturing smaller sizes of blue crabs in this impoundment, as few small juveniles were captured in this area.

A similar frame and net structure was constructed during the last year of the study at the second sampling site (DUP), located in the National Estuarine Research Reserve within the upper reaches of the Duplin River (Fig. 1). The smaller $(0.64 \mathrm{~cm})$ and lighter mesh net used at the SEC site was found to be much more susceptible to damage by blue crabs, so here we used a $1.2 \mathrm{~cm}$ square mesh. Because the drainage of the marsh at the DUP site was not delineated as well as at the SEC site, the $0.64 \mathrm{~cm}$ mesh wire fences extended ca $10 \mathrm{~m}$ from the creek frame onto higher marsh ground that formed the approximate drainage area. The marsh drained by this creek extended out from forested uplands and was bordered along the sides in general by high marsh (including some Juncus sp. found in very high elevation areas). This site had an estimated (from aerial photographs) total surface area of 1.12 ha within the boundaries delineated by the relatively high elevation marsh that defined the drainage area.

We deployed the nets at slack high tide, then pushed a chain attached to the leading edge of the bottom of each net into the mud, effectively sealing the block nets around all sides. Tidal height at slack high tide was measured at the SEC site with a permanent stick gauge, using a scale from 0 to $120 \mathrm{~cm}$ above an arbitrary baseline. At both sites, after most of the water drained from the creek, a shallow rivulet continued to drain in a depression along the center of the creek and a depression provided water along the bottom of the net for crab refuge. Though we did not make extensive searches in all of the upstream areas, we attempted to find crabs remaining in the proximity of the net. All blue crabs captured during a net deployment (sample) were measured to the nearest $\mathrm{mm}$ in carapace width between the tips of the lateral spines, their sex determined, and (if not held for the feeding experiments described below) released downstream.

During most block net deployments at the SEC site, we measured surface water temperature and salinity at slack high tide with an electronic temperature meter and hand held refractometer. Those measurements were also made in the river near the DUP site using a remote sensor/recorder (Hydrolab Datasonde 1) in addition to the above instruments.

Seasonal changes in density. We sampled the SEC site from March 1985 until August 1987 during daytime high tides. The number of samples per period varied, but was such that a group of 2 to 6 samples was taken within a $6 \mathrm{~d}$ (maximum) period of similar tidal amplitude. The number of samples within a group during the winter periods was generally at the lower end of this range due to the consistent absence of crabs. While the 'Results' section indicates the realized sampling frequency, we usually took groups of samples at $2 \mathrm{wk}$, or more frequent, intervals through 1986, after which the sampling periods were usually monthly.

Influence of tidal amplitude and time. In late spring 1986 we conducted a series of experiments during intensive sampling of the SEC site, analyzing the return frequency of crabs to the site and differences in abundance with time of day and tidal amplitude. From May 5 until June 20, we deployed the block net during almost every high tide (day and night) at the SEC site, missing 7 tides at infrequent intervals; every daytime tide was then sampled through June 27.

Daytime samples were those taken when the marsh had flooded entirely during daylight hours and a large portion of the water ebbed from the marsh during at least some daylight (i.e. the initial $1.5 \mathrm{~h}$ of ebb in at least the twilight after sunset). Nighttime samples were those when the marsh had flooded during the dark of night and a large portion of the water ebbed from the marsh during at least some darkness (i.e. the initial $1.5 \mathrm{~h}$ of ebb in at least the twilight before sunrise). Samples taken at other times were labeled interim, in 
that the marsh had flooded at times between full darkness or light.

The average tidal height ( $\mathrm{TH}$, on an arbitrary scale from 0 to $120 \mathrm{~cm}$ ) was $51 \mathrm{~cm}$ TH during this sampling, corresponding to ca $2 \mathrm{~m}$ above mean low water; the range was from 15 to $115 \mathrm{~cm} \mathrm{TH}$. At $40 \mathrm{~cm} \mathrm{TH}$, water covered the marsh up through the lower elevation of the short Spartina zone, covering the periphery of the intermediate Spartina zone to a depth of $\mathrm{ca} 20 \mathrm{~cm}$. At $60 \mathrm{~cm}$ TH virtually the entire impoundment had at least some water coverage, while at $70 \mathrm{~cm}$ TH the water flooded the entire impoundment, with the higher elevation, short Spartina inundated to a depth of 10 to $20 \mathrm{~cm}$. We classified the tide into 3 levels: low $(\leq 40 \mathrm{~cm}$ $\mathrm{TH})_{i}$ intermediate $(>40$ to $70 \mathrm{~cm} \mathrm{TH})$; and high $(>70$ $\mathrm{cm} \mathrm{TH}$ ).

Return frequency. At regular (ca 2 d) intervals from May 12 through June 13, crabs that were captured in daytime samples were tagged and released in water draining downstream of the block net. A stainless steel microwire tag, which was a $0.36 \mathrm{~mm}$ diameter wire segment $2.1 \mathrm{~mm}$ long, was injected into the musculature of the fifth pereiopod (the 'backfin' muscle) through the articulation at the base of that appendage. We injected the tags with an automated injection system (Northwest Marine Technology, Shaw Island, WA 98286, USA), and could detect the completely internal tag with a sensitive magnetic moment detector (Northwest Marine Technology). We also externally tagged all crabs with (individually) numbered tags; these were fastened between the lateral spines of the carapace with either wire or a rubber band. While the external tags were lost if the crab molted, the microwire tags were effectively permanent through multiple molts and did not influence growth or mortality of crabs within the sizes that we captured ( $\geq 35 \mathrm{~mm}$, Fitz \& Wiegert 1991; and see van Montfrans et al. 1986 regarding smaller crabs). Recaptured crabs bearing an external tag were released again after recording the tag's code, whereas recaptures without such identification were dissected in the lab to determine the binary code on the microwire tags (and thus the date of prior release).

Feeding habits. On days alternate to the above mark-release schedule, crabs that we captured for the first time were taken to the laboratory and held in aquaria with (30 um filtered) running seawater for a 24 $h$ period of starvation. We then double-tagged those crabs as above, and released them into the middle of the SEC impoundment (accessed by a boardwalk) ca 30 min before slack high tide (after setting the net). The cod end of the net was then sampled every 45 to 60 min until the impoundment drained completely. Recaptured crabs were immediately placed on ice and frozen for later stomach content analysis.
We followed a procedure similar to that of Carr \& Adams (1973) to sieve-fractionate the stomach contents for easier identification and enumeration of masticated items of widely varying sizes (using sieve mesh sizes of $750,250,125$, and $64 \mu \mathrm{m}$, with a vacuum applied to pull water rinse and contents through). Each fraction was analyzed under a dissecting microscope to estimate the proportional volume occupied by each type of consumed prey. The fractions were then dried at $50^{\circ} \mathrm{C}$ for at least $48 \mathrm{~h}$ and weighed to the nearest $0.1 \mathrm{mg}$. The total percent contribution by each prey category in a stomach was calculated by weighting the prey volume proportion in each size fraction by the fraction's contribution to the mass of the total sample.

Intertidal-subtidal comparisons. We sampled blue crabs in the intertidal zone at the DUP and SEC sites during 5 periods from late May through late August 1987, with 4 or 5 samples per period. Captured crabs were sized, sexed, and released downstream as previously described. During these periods, we also used trawl $(5 \mathrm{~m}$ wide mouth, $1.9 \mathrm{~cm}$ square body mesh, 0.6 $\mathrm{cm}$ mesh cod end liner, tickler chain) tows to sample the blue crab population in a shallow (ca $1.6 \mathrm{~m}$ ) subtidal creek of the Duplin River, in close proximity to the intertidal marsh of the block net site (Fig. 1). The 10 min trawl tows were within the period $2 \mathrm{~h}$ before and after slack low tide, following the daytime high tide sampled with the block nets. We determined the relative abundance of crabs $\geq 35 \mathrm{~mm}$ in the total population from the mean number of crabs captured per trawl tow, with 9 to 10 samples per day over a $5 \mathrm{~d}$ period.

\section{RESULTS}

\section{Temperature and salinity}

Mean water temperature in the DUP and SEC sites ranged from lows near $10^{\circ} \mathrm{C}$ in January to highs near $30^{\circ} \mathrm{C}$ in midsummer. Salinity was more variable over short time periods due to local rainfall, but followed a similar seasonal pattern with lows near 10 to 15 parts per thousand (ppt) in winter and increasing to near 25 to $30 \mathrm{ppt}$ in midsummer. Salinity was higher at SEC compared to the DUP river site by several ppt during many sampling periods; however, there is no direct freshwater riverine input to the Duplin River/Doboy Sound and some of the difference may be due to the comparison of intertidal (SEC) and subtidal (DUP) samples. In the absence of local rain runoff, the freshwater Altamaha River to the south is the nearest freshwater source and influences salinity of the Duplin River area; see Imberger et al. (1983) for aspects of the hydrology of the Duplin River. 
Fig. 2. Callinectes sapidus. Density of blue crabs in 2 size classes (mm carapace width) during daytime sampling in the intertidal zone of the salt marsh at the South End Creek site. Error bars are $\pm 1 \mathrm{SE}$

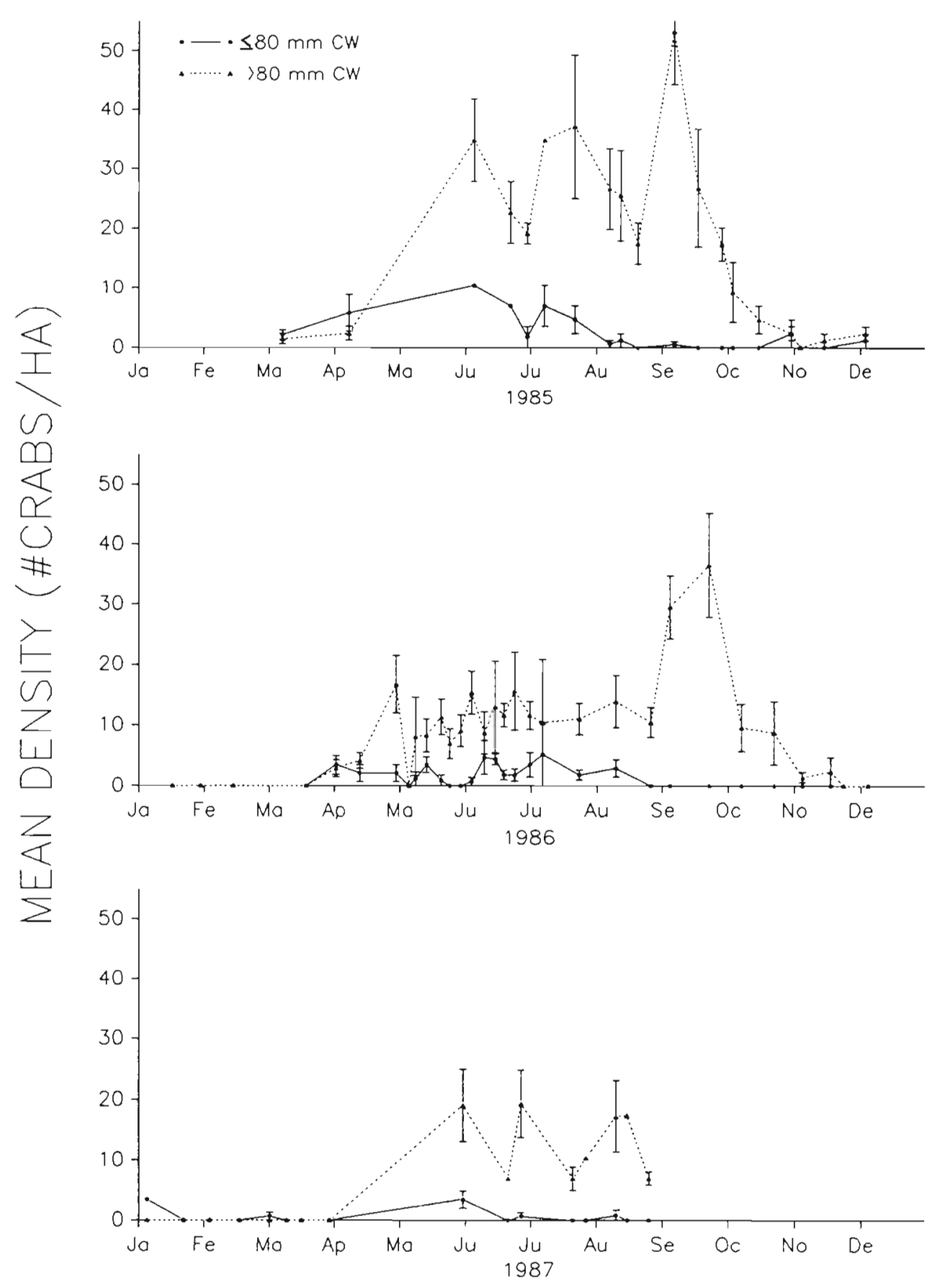

\section{Seasonal changes in density}

Blue crabs began to utilize the SEC site in March or early April, albeit in low total densities of $<5$ crabs $\mathrm{ha}^{-1}$ of total marsh impoundment (daytime samples only; Fig. 2). Water temperature at this time reached ca $15^{\circ} \mathrm{C}$. There was a large gap in sampling from April through May 1985, an interim during which total densities increased from less than $10 \mathrm{crabs} \mathrm{ha}^{-1}$ to ca 45 crabs ha ${ }^{-1}$. Crabs $\leq 80 \mathrm{~mm}$ were predominant in April and increased to $10 \mathrm{crabs} \mathrm{ha}^{-1}$ in June, but the largest change from March to June was due to an increase in crabs $>80 \mathrm{~mm}$. Subsequently we found the larger crabs in much greater densities than those $\leq 80 \mathrm{~mm}$, the former varying in density from near $20 \mathrm{crabs} \mathrm{ha}^{-1}$ to $35 \mathrm{crabs} \mathrm{ha}^{-1}$ through the summer. Density peaked at $>50$ crabs $\mathrm{ha}^{-1}$ in September. Movement into the intertidal area decreased precipitously from late Sep- 
tember through October, having declined to total densities less than 5 crabs ha-1. We captured occasional blue crabs through December, after which none were captured until the following March/April 1986.

Blue crab densities were lower during most of the summer of 1986 compared to the prior year, with fluctuations between 10 and $15 \mathrm{crabs} \mathrm{ha}^{-1}$ through August. Juvenile and adult crabs $>80 \mathrm{~mm}$ were again predominant, with smaller juveniles ( $\leqslant 80 \mathrm{~mm}$ ) present in densities less than 5 crabs ha ${ }^{-1}$. A September increase in movement into the intertidal area resulted in the year's highest densities of $35 \mathrm{crabs} \mathrm{ha}^{-1}$, which was then followed by a steep decline through October and December. The pattern of abundance in 1987 was similar to that seen in the previous year, with crabs $>80 \mathrm{~mm}$ again predominant, and total densities ranged between 10 and 20 crabs $h a^{-1}$ during the summer.

During the summer of 1987 , densities of blue crabs did not differ between the SEC and upriver DUP sites

a TIME/TIDE \# CRABS

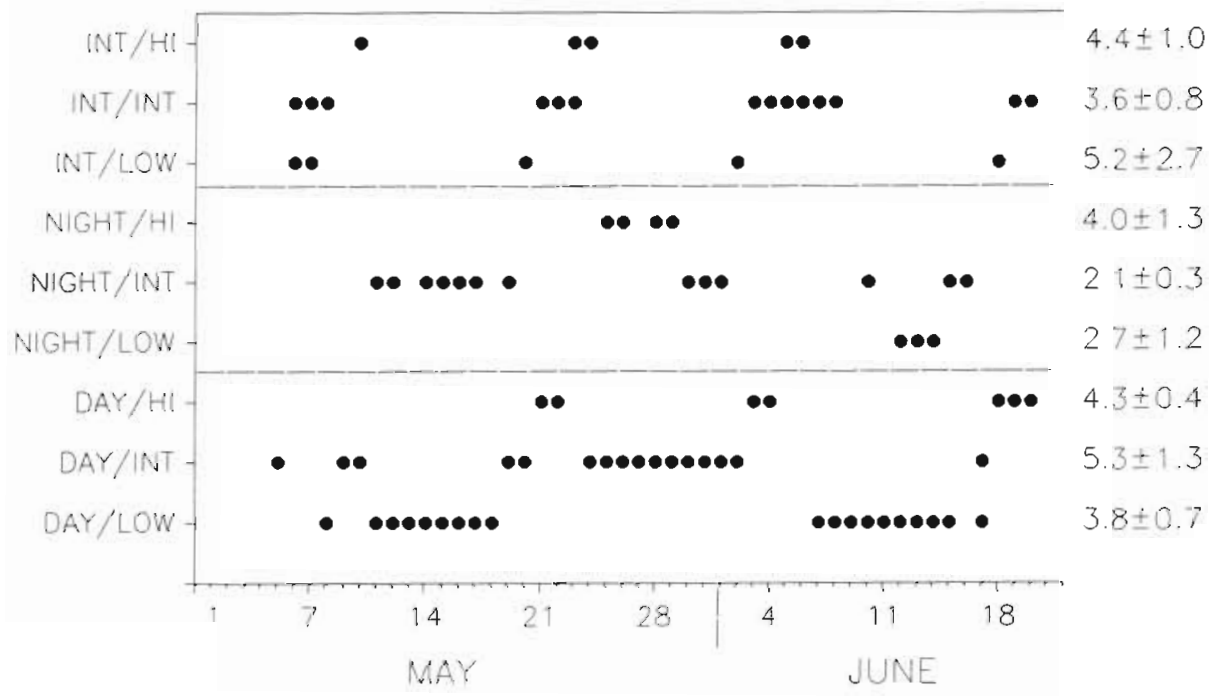

$\mathrm{b}$

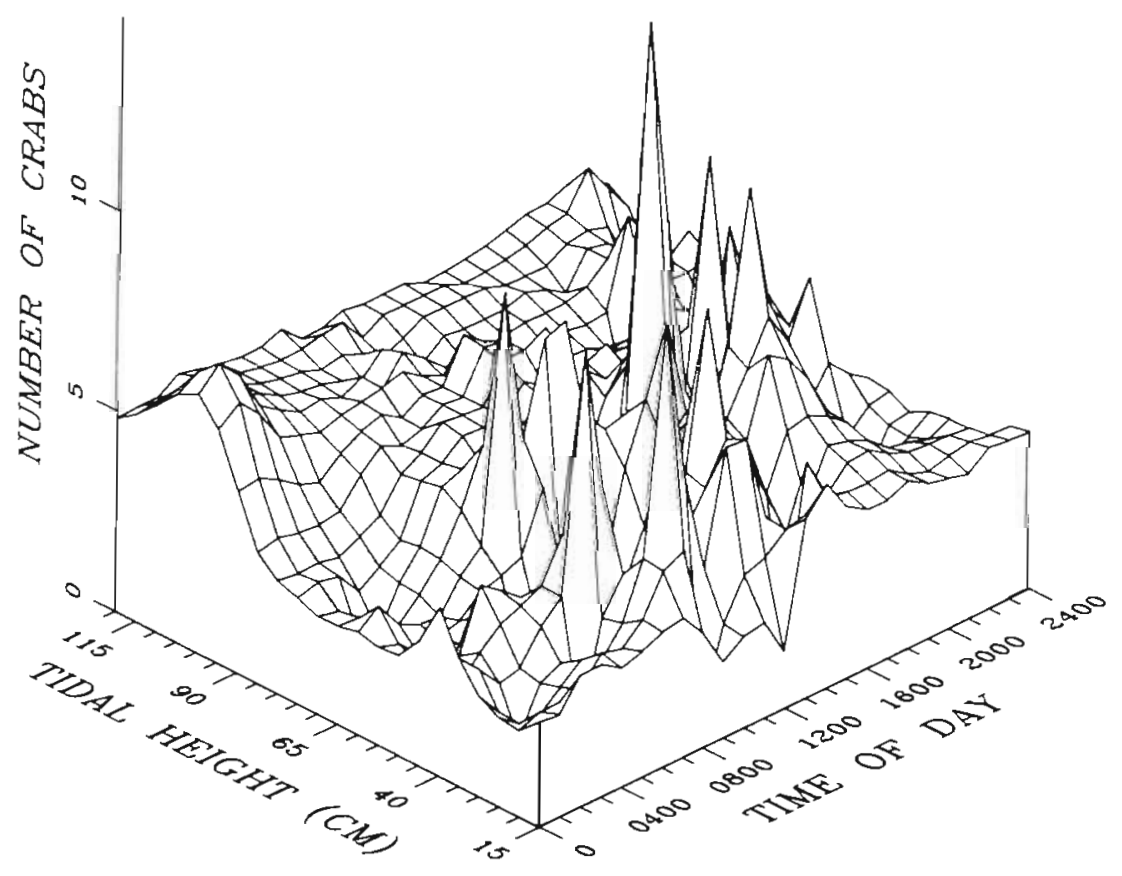

Fig. 3. Callinctes sapidus. (a) Characterization of samples taken at South End Creek during May and June 1986. Three categories of time of high tide and 3 categories of tidal amplitude are indicated: for each (twice daily) sample, TIME/TIDE shows the day, night, or intermediate classification of time at slack high tide, along with the associated low, intermediate, or high classification of tidal amplitude. Mean number of blue crabs captured within all samples of each category are shown, $\pm 1 \mathrm{SE}$. (b) Surface contour plot of the number of crabs caught in the impoundment as a function of tidal height $1 \mathrm{~cm}$ on the TH scale from an arbitrary baseline) and of time of day. All data points are included, with the surface interpolated among the points 
(paired $t$-test, $\mathrm{p}=0.16, \mathrm{df}=20$ ). All statistical procedures were performed using SPSS/PC (Norusis 1984). However, paired $t$-tests within each of 4 size classes showed that there were significantly greater densities within the 2 smallest size classes at the DUP site $(\leq 50 \mathrm{~mm}, \mathrm{p}=0.01 ; 51$ to $80 \mathrm{~mm}, \mathrm{p} \leq 0.001 ; 81$ to $125 \mathrm{~mm}, \mathrm{p}=0.47 ;>125 \mathrm{~mm}, \mathrm{p}=0.18$ ). Densities of blue crabs at the DUP site are presented later for comparison of relative size class frequency between subtidal and intertidal samples.

\section{Influence of tidal amplitude and time}

Comparisons of crab abundance with varying time and height of tide were difficult due to the progressive changes in tidal amplitude over week-long periods and the tidal differences between many day and corresponding night samples. However, the abundance of crabs in the intertidal zone did not change appreciably during the May-June 1986 intensive sampling period (Fig. 2). Therefore, the mean ( $\pm 1 \mathrm{SE}$ ) number of crabs per sample (not density) within the 9 time/height categories are presented in Fig. $3 \mathrm{a}$ for the $1.5 \mathrm{mo}$ period. Although inferential statistics were not used, the greatest differences were those between day and night samples within the intermediate tidal height: with at least 13 samples in each category, there was a mean of $2.1 \pm 0.3$ blue crabs per sample at night, whereas daytime samples averaged $5.3 \pm 1.3$ crabs; (the mean at intermediate times of day was $3.6 \pm 0.8$ crabs). The extent of tidal inundation did not appear to influence blue crab movement into the intertidal zone in any consistent manner, although the daytime samples had a somewhat higher mean number of crabs at intermediate tides than those at the lowest tide. There were very few nighttime samples in the lowest tide category for comparisons. A plot of the number of crabs in the intertidal zone as a dependent function of both tidal height and time of day (Fig. 3b) further indicates that, while abundance was variable, more crabs were captured during daytime hours. Again, no clear pattern in abundance was apparent due to tidal height, although somewhat fewer crabs were captured during the lowest $(<30$ to $40 \mathrm{TH}$ ) tides.

\section{Return frequency}

Of the 107 crabs that were tagged during the intensive May-June sampling, crabs returned on 44 occasions: 28 crabs returned at least once, 7 returned twice, 5 three times, 2 four times, and 2 returned five times. Five crabs had lost the external tag and were removed from the population to decode the microwire tag. A large proportion of the returns to the impoundment occurred within several days of release (Fig. 4), although only one crab was recaptured in the sample immediately following its release. A cumulative $65 \%$ of the total recaptures occurred after 10 tides (5 d), and nearly $85 \%$ of those returning did so within 20 tides (10 d) after release. Multiple returns occurred during the period encompassing 25 tides (12.5 d).

\section{Feeding habits}

On 11 different occasions during the springtime period of intensive sampling, we released a total of 90 crabs into the middle of the impoundment at high tide; 83 were recaptured with the receding tide, indicating that the sampling efficiency of this block net system
Fig. 4. Callinectes sapidus. Return frequency of blue crabs to the area sampled at South End Creek. Number of high tides elapsed since a crab's initial release is shown for crabs that returned between 1 and 5 times. Percent and cumulative percent of total returns represent the proportion of the total number of recaptures that returned within the indicated number of elapsed tides. (Three first-time returns were captured between 46 and 65 tidal cycles after their release and are not shown!

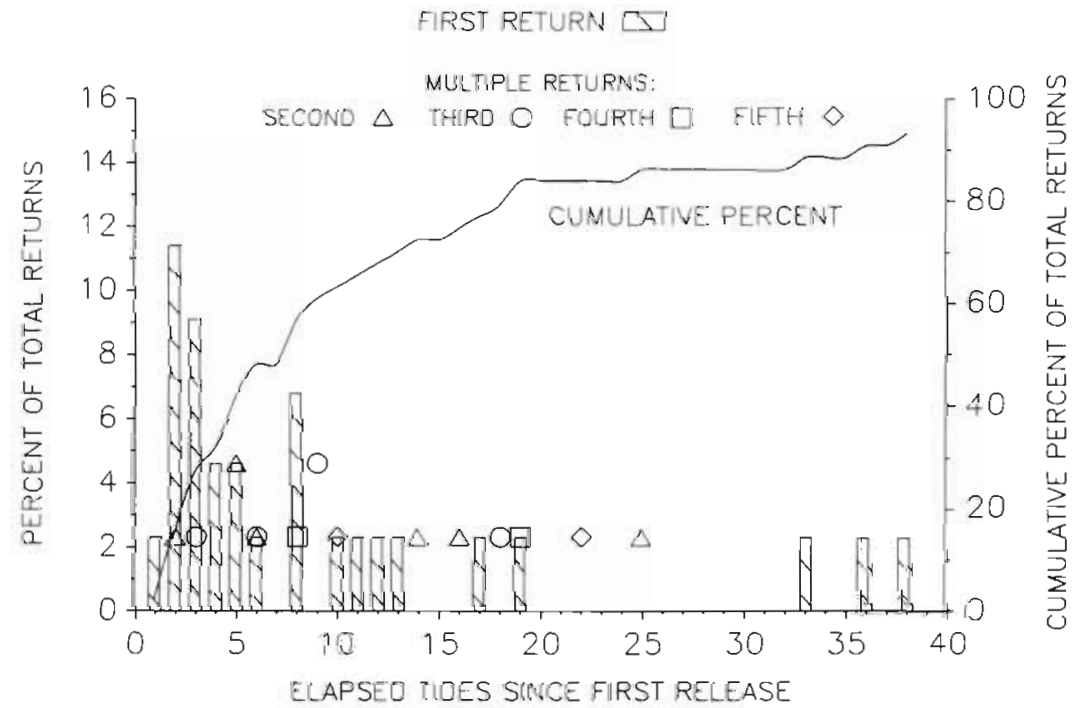


was over $92 \%$. The mean carapace width of the released crabs was $111 \pm 21$ (SD) $\mathrm{mm}$, ranging from 50 to $163 \mathrm{~mm}$ (although only 5 were $\leq 80 \mathrm{~mm}$ ); the smallest crab that was not recaptured was $96 \mathrm{~mm}$.

Eight of 79 dissected crabs had empty stomachs. Most crabs had relatively full stomachs after the mean of slightly over $2 \mathrm{~h}$ foraging within the intertidal area. Fishes and non-portunid crabs were the largest components of the diet, both in terms of mean \% volume and in frequency of occurrence in the stomach samples (Fig. 5). The non-portunid crabs often were not identified to a detailed level, but included $U_{c a}$ sp., grapsid, and xanthid crabs which were resident within the intertidal zone. Those fish and crab prey, in nearly equal proportion, together represented an average of $80 \%$ of the stomach volume, with fish found in $60 \%$ and nonportunid crabs in $66 \%$ of the individual crab stomachs. The category of 'other crustacean' was the next most common component of the diet, constituting ca $12 \%$ of the stomach volume and was found in one third of the crab's stomachs. This category included juvenile penaeid shrimp, palaemonid shrimp, and small peracaridan crustaceans, although juvenile Penaeus sp. appeared to be predominant. Spartina (live and dead) was consumed to some extent, found in $14 \%$ of the stomachs and constituted $1.5 \%$ of the estimated volume. A number of miscellaneous prey were consumed by blue crabs in low frequency, including brachyuran crab larvae, copepods, annelids, gastropods, bivalves, ostracods, and foraminifera.

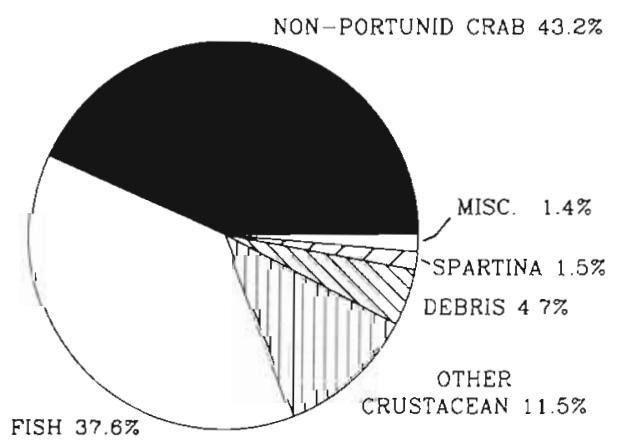

$$
\begin{aligned}
& \text { FREQUENCY } \\
& \text { CRAB: } 0.68 \\
& \text { FISH: } 0.60 \\
& \text { DEBR: } 0.55 \\
& \text { CRUS: } 0.33 \\
& \text { SAND: } 0.33 \\
& \text { SPAR: } 0.14 \\
& \text { LARV: } 0.08 \\
& \text { COPE: } 0.07 \\
& \text { ANNE: } 0.06 \\
& \text { GAST: } 0.04 \\
& \text { BIVA: } 0.03 \\
& \text { OSTR: } 0.03 \\
& \text { FORA: } 0.01
\end{aligned}
$$

Fig. 5. Callinectes sapidus. Feeding habits of blue crabs within the intertidal zone at South End Creek. Pie chart values indicate the mean percent of stomach content volume (excluding sand), while FREQUENCY indicates the proportion of the samples in which each prey item was at least present. CRAB $=$ non-portunid crabs; DEBR = unidentified organic debris CRUS (and OTHER CRUSTACEAN) $=$ penaeid and palaemonid shrimp, along with small peracaridan crustaceans; $\mathrm{SPAR}=$ Spartina alterniflora; LARV = brachyuran crab larvae $;$ COPE $=$ copepods; ANNE $=$ annelids; GAST $=$ gas tropods; $\mathrm{BIVA}=$ bivalves; OSTRA = ostracods; FORA = foraminifera

\section{Intertidal-subtidal comparisons}

The mean size distributions of crabs in the DUP intertidal zone and of crabs captured in the subtidal trawl samples are shown in Fig. 6. While the late May size class distributions were not different between subtidal and intertidal habitats $(\mathrm{p}=0.317)$, the differences between the sample distributions in the 2 habitats were either significant or marginally significant within the late June, July, and August samples (KolmogorovSmirnov, $p=0.006, p=0.046$, and $p=0.003$, respectively).

Because the total sample distributions were different between habitats during several sampling periods, we determined which individual size class(es) had different mean size class frequencies between habitats (Table 1). For each sampling period, we made separate (independent sample) $t$-tests of the arc-sine transformed proportions of each size class (arcsine $p^{0.5} ; p=$ sample proportion) between habitats. There were no consistent departures from the hypothesis that crabs of various sizes moved into the intertidal zone in the same proportion in which they were found in the sub-

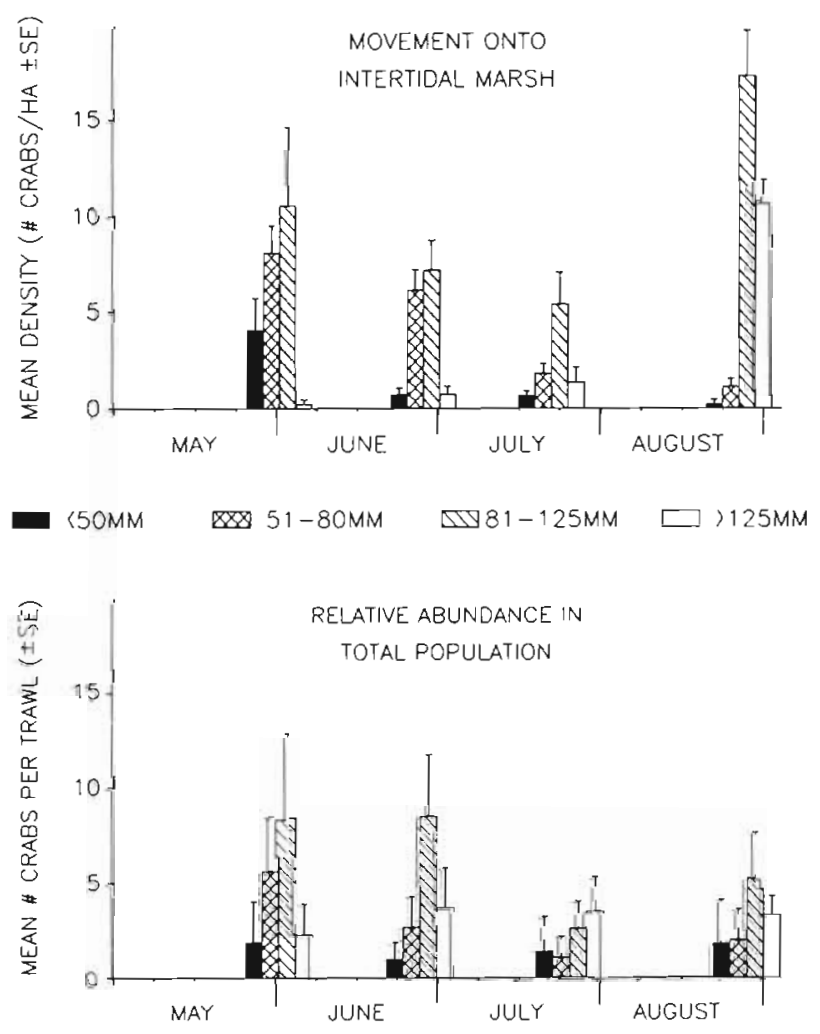

Fig. 6. Callinectes sapidus. Density of blue crabs within the Duplin River intertidal area and their relative abundance within the subtidal population. Means $\pm 1 \mathrm{SE}$ within 4 size classes (mm carapace width) are shown. Each histogram is centered over the date of the midpoint of a sampling period 
Table 1. Callinectes sapidus. Size frequencies of crabs sampled in the subtidal (SubT) and intertidal (InterT) zones during the 4 sampling periods at the DUP site in 1987. Sampling periods started during the final days of each month; values shown within each size class are mean percent of the total sample, $\pm 1 \mathrm{SE}$. Significant differences $(p<0.05)$ between subtidal and intertidal mean proportions determined from separate $t$-tests on arc-sine transformed data (arcsine $p^{05} ; p=$ proportion)

\begin{tabular}{|c|c|c|c|c|c|}
\hline \multirow[t]{2}{*}{ Month } & \multirow[t]{2}{*}{ Habitat } & \multicolumn{4}{|c|}{ Carapace width } \\
\hline & & $\leqq 50 \mathrm{~mm}$ & $51-80 \mathrm{~mm}$ & $81-125 \mathrm{~mm}$ & $>125 \mathrm{~mm}$ \\
\hline May & SubT & $10.0 \pm 2.8$ & $34.1 \pm 6.2$ & $43.0 \pm 7.0$ & $13.0 \pm 2.8$ \\
\hline May & Inter T & $20.2 \pm 8.9$ & $36.5 \pm 6.7$ & $42.2 \pm 14.8$ & $1.0 \pm 1.0$ \\
\hline June & SubT & $5.6 \pm 1.4$ & $17.8 \pm 4.0$ & $53.6 \pm 5.2$ & $23.1 \pm 3.6$ \\
\hline June & Inter T & $7.3 \pm 4.6$ & $41.3 \pm 6.5$ & $47.7 \pm 3.9$ & $3.6 \pm 2.2$ \\
\hline $\begin{array}{l}\text { July } \\
\text { July }\end{array}$ & $\begin{array}{l}\text { SubT } \\
\text { InterT }\end{array}$ & $\begin{array}{r}14.9 \pm 6.5 \\
7.8 \pm 3.0\end{array}$ & $\begin{array}{l}10.7 \pm 2.5 \\
19.8 \pm 5.3\end{array}$ & $\begin{array}{l}33.0 \pm 6.1 \\
53.7 \pm 13.6\end{array}$ & $\begin{array}{l}41.4 \pm 5.1 \\
18.7 \pm 13.0\end{array}$ \\
\hline Aug & SubT & $9.8 \pm 4.1$ & $14.0 \pm 3.8$ & $43.9 \pm 3.3$ & $32.2 \pm 5.3$ \\
\hline Aug & InterT & $1.7 \pm 1.2$ & $6.5 \pm 3.1$ & $58.4 \pm 2.9$ & $33.4 \pm 4.8$ \\
\hline
\end{tabular}

tidal area. Significant differences were within the 3 largest classes at different times: a greater proportion of crabs $>125 \mathrm{~mm}$ was found in subtidal samples (than in intertidal samples) during May and June, whereas the intertidal samples had a greater proportion of crabs within the June, 51 to $80 \mathrm{~mm}$ size class and the August, 81 to $125 \mathrm{~mm}$ size class. Those differences are shown in Table 1, where all nonsignificant differences had $p>0.10$ and all significant differences had $\mathrm{p}<0.01$.

\section{DISCUSSION}

Vegetated salt marsh habitats have been shown to be used as nursery areas to various degrees by small $(<30$ $\mathrm{mm}$ ) juvenile blue crabs (e.g. Mense \& Wenner 1989 , Thomas et al. 1990). However, larger cohorts can also move into this area. Intertidal salt marsh habitats in Georgia were used by both juvenile and adult blue crabs, not merely by the smallest juveniles. Whereas the Kolmogorov-Smirnov test indicated differences in crab size distributions between the intertidal and (source) subtidal samples for 3 of 4 sample dates, tests comparing individual size classes during those dates indicated no consistent statistical (or apparent) trend toward ontogenetic differences in intertidal movements. Thus, during periods of warm water temperature, blue crabs ( $\geq 35 \mathrm{~mm}$ ) appeared to have moved into the intertidal zone at an upriver (DUP) location in close proportion to their abundance in the local source (subtidal) population. Blue crabs moved into the SEC intertidal site primarily during warm months. Densities peaked at ca $50 \mathrm{crabs} \mathrm{ha}^{-1}$ in autumn, then decreased to few or no crabs within that intertidal area from November through February. Dominating the catch from late spring through autumn were subadults and adults $>80 \mathrm{~mm}$, while smaller juveniles ( $\leq 80 \mathrm{~mm}$ ) were most common in March and were present in low abundance through July or August. Although few studies were available for direct comparison, Rozas \& Hackney (1984) reported the numbers of blue crabs captured within an oligohaline marsh in North Carolina. Extrapolation of their data (using approximate areal estimates) indicated that they found a maximum of about $75 \mathrm{crabs}^{\mathrm{ha}} \mathrm{a}^{-1}$ in July. While this was similar to our findings, the mean size of blue crabs that they captured generally averaged well under $50 \mathrm{~mm}$, whereas the maximum density of blue crabs in our study consisted largely of crabs $>80 \mathrm{~mm}$. Regardless, these densities are low $\left(<0.01 \mathrm{~m}^{-2}\right)$ compared to other small macrofauna: Rozas \& Hackney (1984) stated that the number of juvenile blue crabs that they captured was less than $1 \%$ of the catch of individual organisms. However, the total (wet) biomass of blue crabs was a comparatively large proportion (25\%) of the total catch in that study.

Rozas \& Hackney (1984) found small juvenile crabs to be absent or in low abundance within an oligohaline intertidal marsh zone during winter in North Carolina, whereas Shenker \& Dean (1979) captured between 0 and 60 'immature' blue crabs per channel net sample (which drained about 1.67 ha) in 8 samples during their January sampling of a South Carolina intertidal salt marsh creek. Other data from subtidal creeks along Sapelo Island (Fitz 1990) showed that small juvenile blue crabs entered the upper reaches of the Duplin River area from late fall through early spring, and were apparently most abundant in that area compared to habitats downstream. Therefore, the lack of blue crabs in the intertidal zone during the winter at $\mathrm{SEC}$, in close proximity to the Atlantic Ocean, may be 
partially a reflection of low densities of juvenile crabs within the SEC subtidal population during that period. However, given their complete absence in that intertidal area during most of the winter, it is plausible that intertidal movements were curtailed at least to some extent by cold water temperatures and decreased activity levels.

Fluctuations in tidal amplitude are an integral aspect of any salt marsh habitat, but the extent of marsh inundation has rarely been explicitly analyzed as a factor influencing intertidal movements by blue crabs or other macrofauna. Zimmerman \& Minello (1984) recognized that the seasonal periods of prolonged marsh inundation in the Gulf of Mexico may be conducive to greater numbers of natant macrofauna utilizing the marsh surface, providing long periods of utilization of the vegetated habitat. However, the physical characteristics of that region are very different from those of Georgia, where tidal amplitude averages almost $2 \mathrm{~m}$ higher and the tides are driven principally by lunar phases (as opposed to a more pronounced effect of weather systems). While Zimmerman \& Minello (1984) reported significant selection by small juvenile blue crabs for clumps of vegetated salt marsh habitat during extended high tides, we focused on the extent to which the crabs moved into a larger, contiguous, expanse of zone of marsh (and drainage creek) with the tide, most crabs then being forced out of the vegetation in several hours by the tide.

During the 1.5 mo period of twice-daily sampling, we detected a slight difference in the number of blue crabs in the intertidal area due to the tidal amplitude: blue crabs were somewhat less abundant in the intertidal area during daytime tides of the lowest amplitudes, but there was no apparent increase in abundance from intermediate to high tidal amplitudes. Because of the relatively small differences, it appears that there was little change in intertidal utilization with fluctuations in the height of high tide. While there was considerable complexity due to changing tidal amplitude within daily and weekly time frames, this conclusion should have a reasonable degree of confidence, given the frequency of sampling during all tides of a period with little change in total abundance. We expected more crabs to move into the intertidal zone with more extensive and deeper tidal inundation, but it is possible that the crabs merely made little use of the higher zones of the marsh when it was available with high tides.

The numbers of blue crabs that moved into the intertidal area were apparently influenced by diel activity patterns, as we captured a greater number of crabs during the day compared to night. (The intermediate time period could not suitably be included in the comparisons, as that category included both light and dark periods.) Rozas \& Hackney (1984) reported contrary results for smaller juvenile blue crabs in a freshwater intertidal marsh. However, their day samples were separated from night samples by $2 \mathrm{wk}$, and the day/ night paired $t$-test used in their analysis may have been confounded by temporal changes in abundance (as they noted in their day/night comparison of spot Leiostomus xanthurus). Our comparison of day and night samples, during a period of little overall change in abundance and within categories of similar tidal inundation, provided more convincing evidence that blue crabs move into the intertidal zone of the marsh to a greater extent during the day. Blue crabs have welldeveloped chemoreceptive abilities (Pearson \& Olla 1977), but visual stimuli appear to be important during foraging (see Hamilton 1976). The increased daytime movements into intertidal areas may facilitate their foraging activities.

Ryer (1987) found that blue crabs from a Chesapeake Bay marsh creek had greater gut fullness when captured during high tide compared to samples prior to high tide, indicating that the crabs were moving onto the marsh surface to forage. The intertidal zone in this Georgia marsh appeared to be a useful foraging area for blue crabs to obtain natant and resident prey. During a May-June period, large blue crabs preyed heavily on fishes and resident non-portunid crabs; most had relatively full stomachs after 2 to $3 \mathrm{~h}$ within the intertidal zone. Some of the tissue of those prey may have been categorized as part of the unidentified organic debris if the tissue was masticated, although we often could identify soft body parts of organisms such as annelids. Such material that may be quickly assimilated was lost from the analysis, but we minimized this by frequent sampling of the block net so that little digestion occurred. Furthermore, the frequency of occurrence of an. identifiable part of each prey (such as the jaws and/or setae of nereid polychaetes) within the stomach samples provided another indication of the extent of predation by blue crabs on each prey category, complementing the volume estimates for the assessment of feeding habits of the free-ranging blue crabs.

While gastropods, bivalves and annelids were present within this marsh, evidence of their ingestion by blue crabs appeared in less than $6 \%$ of the stomachs. Hamilton (1976) demonstrated extensive predation by blue crabs on the gastropod Littorina irrorata in a Florida marsh; West \& Williams (1986) found significant predation on that gastropod by blue crabs enclosed within cages in a Alabama marsh. Although we found that blue crabs preyed to some extent on small gastropods, there was no evidence of predation on Littorina in this study nor in another study of blue crab feeding habits in subtidal marsh creeks (Fitz 1990). Among-study differences in availability of other prey for this opportunistic predator, and/or cage- 
induced behavioral differences, may be responsible for the lack of Littorina feeding observed in this study. For example, the relatively high densities of $\geq 1$ enclosed crab $\mathrm{m}^{-2}$ used in past cage enclosure studies (Virnstein 1977. West \& Williams 1986) may have altered the normal foraging behavior of an adult crab, such that it sought the most readily available food.

An important aspect of trophic dynamics and biomass loss from a local area incorporates predation and subsequent export of assimilated biomass and feces to other areas. Whereas a specific, possibly unchanging, number of blue crabs may consume resources in an intertidal marsh area, emigration from the local blue crab population that is concurrent with influx of new individuals represents a higher rate of gross loss from the entire local system than is evident from net changes in local abundance. Even though the abundance of blue crabs in the intertidal site at SEC did not change appreciably during the May-June 1986 sampling, residency within the local population appeared to be short, with few crabs returning to the area after $10 \mathrm{~d}$. Thus the predation pressure within the sampled area was relatively constant, but secondary production consumed by blue crabs appeared to have been exported from that local salt marsh system within this brief period, indicative of a greater (gross) rate of export of biomass than was otherwise apparent.

There have been few estimates of the densities of juvenile and adult blue crabs within intertidal habitats, and no reports of their free-ranging feeding habits in the intertidal zone or of their local residency. While blue crabs may be present at relatively low densities in the intertidal zone compared to smaller organisms, predation by this large consumer within this zone may have greater direct and indirect effects on the community than their densities suggest. In a caging study, Kneib (1988) described the interactions between 2 predators in the intertidal salt marsh and their effect on the infaunal community. Hines et al. (1990) provided evidence of the direct and indirect influence of blue crabs and other epibenthic predators on the community structure of subtidal infauna, pointing out the spatial and temporal variability in responses. Further experimental approaches and the use of biotelemetry (Wolcott \& Hines 1989) could be used to better determine patterns and effects of foraging by blue crabs in intertidal areas; multispecies simulation modeling is a useful, complementary tool to investigate salt marsh trophic dynamics. Our results provide a foundation for such analyses of the extent to which blue crabs affect the biota within the intertidal zone of the salt marsh.

Acknowledgements. We thank T Adler, M. Miller, and J. Schubauer for their assistance in the field sampling. A.G. Chalmers, R.T Kneib, and 2 anonymous reviewers provided helpful comments on earlier drafts of this manuscript. This work is a result of research sponsored by NOAA Office of Sea Grant, Department of Commerce, under Grant \#NA84AA-D00072 . The U.S. Government is authorized to produce and distribute reprints for governmental purposes notwithstanding any copyright notation that may appear hereon. This is contribution no. 682 from the University of Georgia Marine Institute.

\section{LITERATURE CITED}

Archambault, J. A., Wenner, E. L., Whitaker, J. D. (1990). Life history and abundance of blue crab, Callinectes sapidus Rathbun, at Charleston Harbor, South Carolina. Bull. mar. Sci. 46: 145-158

Arnold, W. S., Kneib, R. T. (1983). The size distribution of blue crabs (Callinectes sapidus Rathbun) along a tidal gradient in a Georgia salt marsh. Ga J. Sci. 41: 93-94 (abstract)

Bozeman, E. L., Dean, J. M. (1980). The abundance of estuarine larval and juvenile fish in a South Carolina intertidal creek. Estuaries 3: 89-97

Carr, W E., Adams, C. A. (1973). Food habits of juvenile marine fishes occupying seagrass beds in the estuarine zone near Crystal River, Florida. Trans. Am. Fish. Soc. 103: 511-514

Churchill, E. P., Jr (1919). Life history of the blue crab. Bull. U.S. Bur Fish. 36: 95-128

Darnell, R. M. (1958). Food habits of fishes and large invertebrates of Lake Pontchartrain, Louisiana. Contr. mar. Sci. Univ. Tex. 5: 353

Darnell, R. M. (1959). Studies of the life history of the blue crab (Callinectes sapidus Rathbun) in Louisiana waters. Trans. Am. Fish. Soc. 88: 294-304

Dudley, D. L., Judy, M. H. (1973). Seasonal abundance and distribution of juvenile blue crabs in Core Sound, N.C. 1965-1968. Chesapeake Sci. 14:51-55

Fitz, H. C. (1990). The utilization of a salt marsh estuary by the blue crab, Callinectes sapidus. Dissertation, University of Georgia, Athens

Fitz, H. C., Wiegert, R. G. (1991). Tagging juvenile blue crabs, Callinectes sapidus, with microwire tags: retention, survival, and growth through multiple molts. J. Crust. Biol. 11: 229-235

Hamilton, P. V (1976). Predation on Littorina irrorata (Mollusca: Gastropoda) by Callinectes sapidus (Crustacea: Portunidae). Bull, mar Sci. 26: 403-409

Hines, A. H., Haddon, A. M., Wiechert, L. A. (1990). Guild structure and foraging impact of blue crabs and epibenthic fish in a subestuary of Chesapeake Bay. Mar. Ecol. Prog. Ser. 67: 105-126

Hines, A. H., Lipcius, R. N., Haddon, A. M. (1987). Population dynamics and habitat partitioning by size, sex, and molt stage of blue crabs Callinectes sapidus in a subestuary of central Chesapeake Bay. Mar. Ecol. Prog. Ser. 36: 55-64

Imberger, J., Berman, T., Christian, R. R., Sherr, E. B., Whitney, D. E., Pomeroy, L. R., Wiegert, R. G., Wiebe, W. J. (1983). The influence of water motion on the distribution and transport of materials in a salt marsh estuary. Limnol. Oceanogr. 28: 201-214

Kneib, R. T. (1988). Testing for indirect effects of predation in an intertidal soft-bottom community. Ecology 69: 1795-1805

Laughlin, R. A. (1982). Feeding habits of the blue crab, Callinectes sapidus Rathbun, in the Apalachicola estuary, Florida. Bull. mar. Sci. 32: 807-822

Mclvor, C. C., Odum, W. E. (1986). The flume net: a quantita- 
tive method for sampling fishes and macrocrustaceans on tidal marsh surfaces. Estuaries 9: 219-224

Mense, D. J., Wenner, E. L. (1989). Distribution and abundance of early life history stages of the blue crab, Callinectes sapidus, in tidal marsh creeks near Charleston, South Carolina. Estuaries 12: 157-168

Norusis, M. J. (1984). SPSS/PC for the IBM PC/XT, Release 1 1. SPSS Inc., Chicago

Orth, R. J., van Montfrans, J. (1987). Utilization of a seagrass meadow and tidal marsh creek by blue crabs Callinectes sapidus. I. Seasonal and annual variations in abundance with emphasis on post-settlement juveniles. Mar. Ecol. Prog. Ser. 41: 283-294

Pearson, W. H., Olla, B. L. (1977). Chemoreception in the blue crab, Callinectes sapidus. Biol. Bull. mar, biol. Lab., Woods Hole 153: 346-354

Perry, H. M. (1975). The blue crab fishery in Mississippi. Gulf Res. Rep. 5: 39-58

Rozas, L. P., Hackney, C. T. (1984). Use of oligohaline marshes by fishes and macrofaunal crustaceans in North Carolina. Estuaries 7: 213-224

Ryer, C. H. (1987). Temporal patterns of feeding by blue crabs (Callinectes sapidus) in a tidal-marsh creek and adjacent seagrass meadow in the lower Chesapeake Bay. Estuaries 10: $136-140$

Shenker, J. M., Dean, J. M. (1979). The utilization of an intertidal salt marsh creek by larval and juvenile fishes: abundance, diversity and temporal variation. Estuaries 2: $154-163$

Subrahmanyam, C. B., Coultas, C. L. (1980). Studies on the animal communities in two north Florida salt marshes, Part

This article was submitted to the editor
III. Seasonal fluctuations of fish and macroinvertebrates. Bull. mar. Sci. 30: 790-818

Tagatz, M. E. (1968). Biology of the blue crab, Callinectes sapidus Rathbun, in the St. Johns River, Florida. Fish. Bull. U. S. $67: 17-33$

Thomas, J. L., Zimmerman, R. J., Minello, T J. (1990). Abundance patterns of juvenile blue crabs (Callinectes sapidus) in nursery habitats of two Texas bays. Bull. mar. Sci. 46: $115-125$

van Montfrans, J., Capelli, J., Orth, R. J., Ryer, C. H. (1986). Use of microwire tags for tagging juvenile blue crabs (Callinectes sapidus Rathbun). J. Crust. Biol. 6: 370-376

Virnstein, R. W. (1977). The importance of predation by crabs and fishes on benthic infauna in Chesapeake Bay. Ecology 58: 1199-1217

Weinstein, M. P. (1979). Shallow marsh habitats as primary nurseries for fishes and shellfish, Cape Fear River, North Carolina. Fish. Bull. U. S. 77(2): 339-357

West, D. L., Williams, A. H. (1986). Predation by Callinectes sapidus (Rathbun) within Spartina alterniflora (Loisel) marshes. J. exp. mar. Biol. Ecol. 100: 75-95

Wilson, K. A., Able, K. W., Heck, K. L., Jr (1990). Habitat use by juvenile blue crabs: a comparison among habitats in southern New Jersey. Bull. mar. Sci. 46:105-114

Wolcott, T. G., Hines, A. H. (1989). Ultrasonic biotelemetry of muscle activity from free-ranging marine animals: a new method for studying foraging by blue crabs (Callinectes sapidus). Biol. Bull. mar. biol. Lab., Woods Hole 176: 50-56

Zimmerman, R. J., Minello, T. J. (1984). Densities of Penaeus aztecus, Penaeus setiferus, and other natant macrofauna in a Texas salt marsh. Estuaries 7: 421-433

Manuscript first received: March 15, 1991 Revised version accepted: August 9, 1991 